\title{
Soft-part preservation in two species of the arthropod Isoxys from the middle Cambrian Burgess Shale of British Columbia, Canada
}

\author{
Diego C. García-Bellido, Jean Vannier, and Desmond Collins \\ Acta Palaeontologica Polonica 54 (4), 2009: 699-712 doi: http://dx.doi.org/10.4202/app.2009.0024
}

More than forty specimens from the middle Cambrian Burgess Shale reveal the detailed anatomy of Isoxys, a worldwide distributed bivalved arthropod represented here by two species, namely Isoxys acutangulus and Isoxys longissimus. I. acutangulus had a non-mineralized headshield with lateral pleural folds (= "valves" of previous authors) that covered the animal's body almost entirely, large frontal spherical eyes and a pair of uniramous prehensile appendages bearing stout spiny outgrowths along their anterior margins. The 13 following appendages had a uniform biramous design-i.e., a short endopod and a paddle-like exopod fringed with marginal setae with a probable natatory function. The trunk ended with a flap-like telson that protruded beyond the posterior margin of the headshield. The gut of $I$. acutangulus was tube-like, running from mouth to telson, and was flanked with numerous 3D-preserved bulbous, paired features interpreted as digestive glands. The appendage design of $I$. acutangulus indicates that the animal was a swimmer and a visual predator living off-bottom. The general anatomy of Isoxys longissimus was similar to that of I. acutangulus although less information is available on the exact shape of its appendages and visual organs. I. longissimus is characterized by extremely long anterior and posterior spines. There are now seven Isoxys species known with soft-part preservation, I. acutangulus, I. longissimus from the Burgess Shale, I. auritus and I. curvirostratus from the Maotianshan Shale of China, I. communis and I. glaessneri from the Emu Bay Shale of Australia and I. volucris from Sirius Passet in Greenland. The frontal appendages of Isoxys strongly resemble those of other Cambrian arthropods, characterized by a single pair of "great appendages" with a shared prehensile function yet some variability in length and shape.

Key words: Arthropoda, Isoxys, "great appendage”, Burgess Shale, Lagerstätten, Cambrian.

Diego C. García-Bellido [Diego.GBC@geo.ucm.es], Departamento de

Paleontología, Instituto de Geología Económica (CSIC-UCM), Facultad de

Ciencias Geológicas, José Antonio Novais 2, 28040-Madrid, Spain; Jean

Vannier [jean.vannier@univ-lyon1.fr], Université de Lyon,

Université Lyon 1, UMR 5125 PEPS «Paléoenvironnements et

Paléobiosphère», Campus de la Doua, Bâtiment Géode, F-69622

Villeurbanne Cedex, France; Desmond Collins [suzanne.collins029@sympatico.ca], 501-437

Roncesvalles Ave., Toronto, Ontario M6R 3B9, Canada. 
This is an open-access article distributed under the terms of the Creative Commons Attribution License (for details please see creativecommons.org), which permits unrestricted use, distribution, and reproduction in any medium, provided the original author and source are credited.

FoF $\underline{\text { Full text }(1,716.2 \mathrm{kB})}$ 